\title{
Integrating foreign higher education institution (HEI) students to Finnish working life
}

\author{
Kaari, Pia ${ }^{\text {a }}$; Ollanketo, Anna ${ }^{\text {b }}$
}

${ }^{a}$ Department of International Business and Culture, South-Eastern Finland University of Applied Sciences, Finland, ${ }^{b}$ Department of Digital Economy, South-Eastern Finland University of Applied Sciences, Finland

\begin{abstract}
According to the Statistics Finland (2017) the unemployment rate of foreigners and citizens of foreign background is approximately double compared with the respective rate of original Finns. Unemployment among young generations is also higher than in older age groups.

According to the research of Centre for International Mobility (2016 $\left.{ }^{1}\right)$, many foreign degree students would like to stay and find employment in Finland after their graduation. The problem, however, is that the companies interested in recruiting foreign students and the foreign graduates don't meet each other.
\end{abstract}

At the same time, Finland is undergoing a structural change in the working life. Finland has evolved from forestry-based to technology-based economy, and is now under a further transition to service-dominated society (Vesikansa 2008). It is therefore of utmost importance to increase the competitiveness and growth, for which Finland needs all the know-how and competencies available in the country.

The aim of the Kilkas project was to promote the employment of foreign students of Finnish Universities of Applied Sciences (UASs) by developing a model for the staff and students. In addition, the project group piloted and reported agile experiments in practical training, alumni work, career guidance, Finnish language teaching and networking with companies

Keywords: Employability; foreign students; employment model; practical training; working life; networking 


\section{Introduction}

International students are a resource for Finland and for Finnish companies, but to some extent not that well known nor utilized in the business life. One could claim that the international students are a forgotten potential when renewing and reviving the Finnish businesses. For example, if a Finnish company aims to start global operations, it could very well use international students for their professional skills, but especially due to their cultural and language knowledge. There are many challenges with regard to international students getting employed in Finland. Among the most important ones are the lack of Finnish language skills, lack of networks and lack of work experience in Finland. In addition, companies have not yet perceived the varied potential of foreign students studying in the Finnish higher education institutions.

Finnish Universities of Applied Sciences (UASs) have been willing - during their 22 years of existence - to promote international students' employment and integration in Finland. However, as some of the obstacles are diminishing, new challenges are rising. In 2016, a coalition of Finnish UASs tackled this problem and created a project network called “ Kilkas - Competitiveness and Growth in Promoting the Employment of Foreign UAS students". The project received ESF funding for 2016-2018 with the aim to develop a practical, well-functioning model whereby the chances of UAS foreign students to find employment in Finland could be better. The interactive model is open for public at www.xamk.fi/kilkas.

As its overall objective, Kilkas project was to design a model to the Universities of Applied Sciences to promote employment of foreign students. Several different domains of students' study paths were thoroughly screened in order to find the weakest links and the points of development. The project concentrated on incorporating the employment perspective into a series of study units (especially Finnish language), study counselling, thesis process, internships and networking with the companies and with the alumni. Towards the end of the project, information on the results were disseminated to the network of Finnish UASs, to the UAS personnel, regional interest groups and several companies. Dissemination of the results was carried out in different forms: by writing a blog and organizing networking events, seminars, infosessions and workshops.

Altogether about 40 members of teaching staff around Finland were involved in the development work. In addition, international students from different faculties of participating UASs were interviewed, and companies' point of views were collected by interviews, study reviews and discussions. 


\section{Background}

A labour market is a place where employers and workers interact with each other. Labour market comprises of the number of the vacancies, the fields of the vacancies, the terms of employment, and, on the other hand, the number of people looking for a job and their training and professional backgrounds. The labour market changes all the time. Sometimes there is a high demand of employees in a certain field and sometimes it can be very low. (Surakka \& Rantamäki, 2013.)

As an immigration country Finland is very young, which also explains Finnish people's slightly negative attitude and image towards the immigration. On the other hand, the attitude towards work-related immigration is more positive. (Ministry of the Interior, 2013.) In 2017, Finland's total unemployment rate was $8,4 \%$, and rate of foreigners $15,8 \%$ (Statistics Finland, 2017). Like in many other countries, the proportion of entrepreneurs among immigrants is larger than among the total population. Immigrants are more willing to take and tolerate risks than the local population. For some, starting up ones own business is the only option for employment. (Martikainen, Saukkonen \& Säävälä, 2013.)

The number of immigrants is steadily growing in Finland, and in the twentieth century it has doubled. Still the number of immigrants is low compared to the other European countries due to the minor need for labor, language barrier and Finland's distant location (International Organization for Migration, 2013, 4-5). The overall number of HEI degree students in Finland in 2016 was 21061 students and of that number, 9867 were studying for a degree in a university of applied sciences. The share of international students of all HEI students in Finland is $7,1 \%$, which is above the average of the OECD countries. (Finnish National Agency for Education, 2016 ${ }^{1}$.)

Studying a higher education degree abroad is a globally growing phenomenon. Especially Asian students seek education outside their home countries. Also in Finland international students are considered as an important aspect for the internationalization of higher education. Until 2017, there were no tuition fees in HEI degrees in Finland. Since autumn 2017, the HEIs in Finland have been in a new situation as they needed to start collecting tuition fees from students outside the European Union and the European Economic Area. It is likely that tuition fees will have an influence on the number of international degree students, the distribution of nationalities, and the internationalization of HEIs overall. (Finnish National Agency for Education, 2016².)

Most of the foreigners who have completed a degree in Finland are living in Finland after five years of graduation. Nearly half of them are in the working life, a small number has continued studying, and about one fifth of them are staying in the country for some other reason such as being unemployed or on training that does not lead to a degree. $32 \%$ of the foreign graduates have left the country. (Centre for International Mobility, 2016 ${ }^{2}$.) If a 
foreign student does not conduct the practical training in Finland during his studies, he may find it difficult to find a job in Finland after the graduation. Employers appreciate the work experience gained in Finland because then they can expect the student is able to work according to the Finnish working life rules. The study doesn't tell in what kind of positions the foreign graduates have been employed. (Centre for International Mobility, 2016 ${ }^{1}$.)

Foreign HEI students are a desired group of immigrants. The aim is to internationalize universities and their degree programmes, and bring foreign students' know-how to the Finnish society. Foreign students could have a significant influence to the country's economy if they stayed in Finland and got employed after the graduation. When choosing a studying country, future employment possibilities is one of the contributing factors. And it must noticed that many international students would like to stay in the country where they complete their degree. (Finnish National Agency for Education, 2016².)

\section{The model of international student's path to employment.}

The developing process of the model of international student's path to employment (Figure1) was started by describing the study path of an international student.

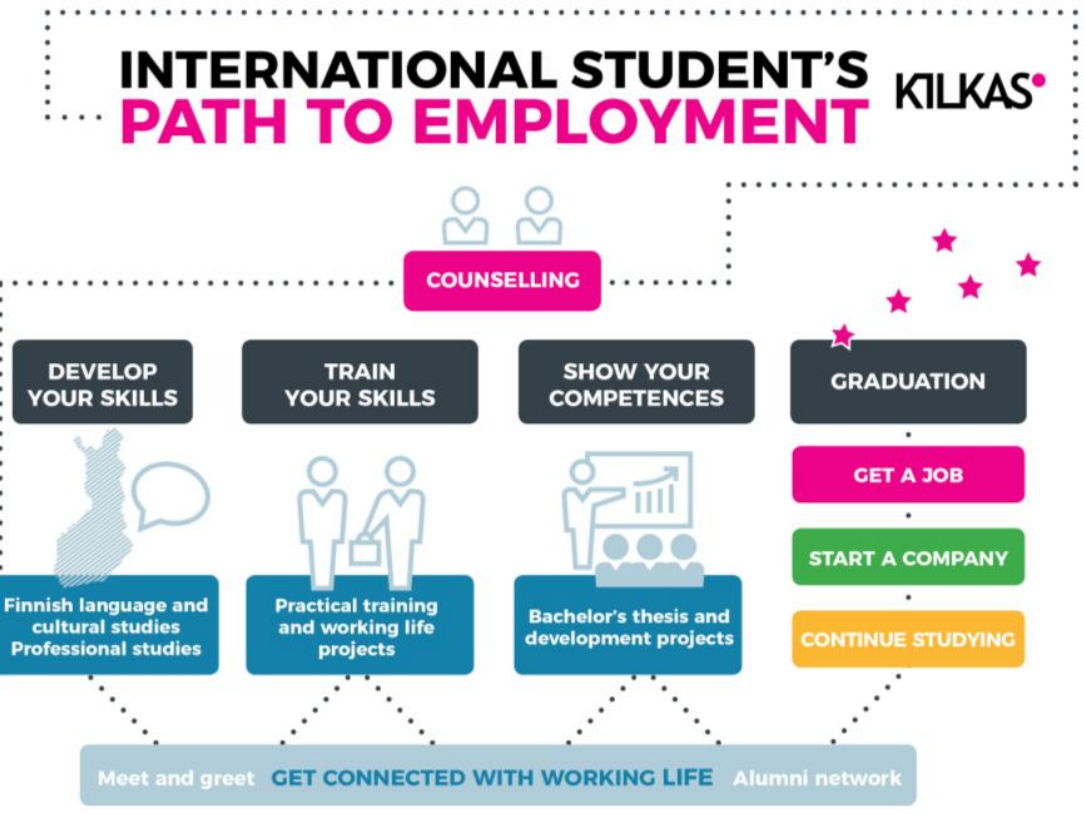

Figure 1. The model of international student's path to employment. 
The most important phases of a curriculum - from the employability perspective - were depicted. After processing the draft picture in several meetings and workshops, the project group agreed that there must to be two different versions:

1) Model in Finnish for lecturers, study counsellors and other interest groups. This model includes descriptions of the agile experiments carried out during the project: new models of practical training, Finnish language course experiments, alumni development work, worklife projects, career counselling pilots etc.

2) Model in English for students. This model is a student-friendly version which helps and guides international students to understand what kind of study units and what kind of activities would support their future employment in Finland.

The Finnish version of the model serves as a general description of how to promote the employability of an international student in Finland. This model can be used e.g. in developing the curricula of the international degree programmes. In addition, it is very practical when orientating new teaching staff to the "employability mind set".

The model describes international student's study path from the beginning of studies to the graduation. This model doesn't introduce the whole curriculum and its detailed contents, but concentrates on those phases of studies (or study modules) that support students' integration and networking, and finally employment in Finland. The model shows the essential development targets and the agile experiments that were piloted during the project.

\subsection{Develop your skills}

In the beginning of studies students focus on gaining information on school, study methods and a new cultural environment. It is for everybody's benefit that international students have a smooth start and integrate easily to the new environment. The first courses include e.g. cultural knowledge, language studies and networking skills. The importance of learning a Finnish language cannot be emphasized enough: in Finland even moderate Finnish skills are almost always a precondition for employment (Lantta, 2017).

\subsection{Train your skills}

When a student continues his studies he needs to complete a practical training period in a company or public organization. Ideally, the student would find a training place in Finland and learn the Finnish working life customs and cultural aspects. In addition, the students could build networks during the training for future employment purposes. Unfortunately only few students find a training place in Finland and therefore most of the students need to return to their home countries or elsewhere, e.g. to Europe, to complete their training period. In the Kilkas project the partners piloted different forms of practical training, such as virtual working and tandem training. The idea for these new forms was to help students 
to find training places more easily. For example if a company is located geographically far or if a company doesn't have room for more personnel, they could offer a virtual training place where meetings could be held through Skype or videoconferencing. In this type of training, the equipment, programmes and networks need to be appropriate and functional. In the tandem training, the international student completes the training together with a Finnish student. The idea is to integrate international students to the Finnish organizational and business culture. In addition, the Finnish student can help the international student in different situations and take more responsibility in the tasks that require knowledge of the Finnish language.

One of the most important factors that promotes employment is that the UAS is connected with companies which can provide real project work for students. These assignments can be incorporated into relevant study units. International students are very often used to theoretical lecturing in the school environment, and real assignments from local companies can be an eye opening experience. As a pedagogical approach, project based learning (PBL) is more and more common in Finland, and it has been noticed that this approach can be useful when integrating students into the working life.

\subsection{Show your competences}

At the end phase of their studies, students write their theses. The purpose of the thesis is to teach the student academic writing and research skills as well as independent working. Equally important is that the student deepens his knowledge of the field he is specializing in. It is a common practice in the UASs in Finland that the topics for theses are given by companies or public organizations. Usually this is a motivational factor for the student: he has a real case to study, and in the best case can present new perspectives and solutions to the problem given. From the student employability perspective, the supervisor of the thesis as well as the company play an important role. The supervisor can support and guide the student to find a topic from such companies that might be able to recruit him at a later stage. In addition, it is has been noticed that if the collaboration between the student, the supervisor and the company is close during the process, the chances for employment increase.

\subsection{Graduation}

When the student graduates, he will, in the best possible case, be employed in his own field of work. Sometimes international students are willing to continue with master studies or consider setting up their own business. The latter option has sometimes been the only, though excellent, alternative to foreigners residing in Finland to find employment. 


\subsection{Counselling and networking}

At the top of the model there is "Counselling". In order to have a smooth start, proper counselling is of utmost importance to international students. One of the main findings of the Kilkas project was that the student counselling should cover the whole, approximately 3.5-year, study path. At the early stage of the studies guidance should concentrate on supporting the foreign students in adjusting to the new environment and the new way of studying. However, after the first year, the counselling should be more employmentoriented. Usually counselling of an international student is more demanding than that of a native Finn, because of the adaptation to a foreign country, culture and educational environment can be challenging and also require more time and resources from the counsellor.

At the bottom of the model there is a wide range of different forms of stakeholder cooperation. It is important that the students create contacts with the Finnish people and understand the Finnish culture and lifestyle, but first and foremost learn to approach and build networks with local businesses, i.e. potential employers. One of the important network channels for both the students and the UASs is the alumni. During the project, it was noticed that in many UASs this important stakeholder group has not been utilized to the full extent. In Kilkas project a model for starting and developing alumni collaboration was created. In addition to alumni networks, other forms of networking channels were also examined. New ways of fostering the existing UAS and working life connections were developed, and new forms of company visits were also experimented.

\section{Conclusions}

The model we have developed and the agile experiments within are a description of the elements that are crucial when promoting the employability of an international student in Finland. Courses on culture, business environment and Finnish language, internships and working life projects, thesis process, networking and alumni activities as well as proper counselling are all important components that should be linked to each other. One of the most important observations of the Kilkas project was that supervisors and supporting staff should possess "employment perspective" in their own roles. In other words, the employment of an international student should be a common goal shared by everybody in the process.

In every part of the model, there are still areas to be developed. Many practical steps are needed to make true changes towards a common mindset of promoting student's employability. HEIs should support international students' employment by offering practical information on Finlands' labour market and how to seek and apply for a job in 
Finland. Especially collaboration with the companies should be further intensified as it is the key route to real working-life connections.

\section{References}

Centre for International Mobility. (2016 1). Faktaa Express 1A/2016: Suomessa, töissä, muualla? Korkeakoulututkinnon suorittaneiden ulkomaalaisten tilanne 5 vuoden kuluttua valmistumisesta. Retrieved 9 February 2018 from http://www.cimo.fi/instancedata/prime_product_julkaisu/cimo/embeds/cimowwwstruct ure/89972_FaktaaExpress1A_2016.pdf

Centre for International Mobility. $\left(2016^{2}\right.$ ). Valtaosa korkeakoulujen ulkomaalaisista tutkinto-opiskelijoista jää Suomeen valmistuttuaan. Retrieved 9 February 2018 from http://www.cimo.fi/ajankohtaista/mediatiedotteet/101/1/valtaosa_korkeakoulujen_ulko maalaisista_tutkinto-opiskelijoista_jaa_suomeen_valmistuttuaan

Finnish National Agency for Education. Opetushallitus 2016². Faktaa Express 6A/2017: Tilastoja ulkomaalaisista tutkinto-opiskelijoista Suomen korkeakouluissa 2016. $\begin{array}{llll}\text { Retrieved } & 2 & \text { January } & 2018 \\ & \text { from }\end{array}$ http://www.cimo.fi/instancedata/prime_product_julkaisu/cimo/embeds/cimowwwstruct ure/164549_FaktaaExpress6A_2017.pdf

Finnish National Agency for Education. Opetushallitus 2016². Faktaa Express 1A/2016: Suomessa, töissä, muualla? Retrieved 4 January from http://www.cimo.fi/faktaa_express_1a_2016

International Organization for Migration (2013). The world migration report 2013. Migrant well-being and development. Geneva: International Organization for Migration.

Lantta, E. (2017). Tehokkaasti Työelämään. Questionnaire of Employment for Companies in Finland.

Martikainen, T., Saukkonen, P. \& Säävälä, M., (2013). Muuttajat. Kansainvälinen muuttoliike ja suomalainen yhteiskunta. Tallinna: Raamatutrukikoda, 223-224; 226.

Ministry of the Interior (2013). Maahanmuuton tulevaisuus 2020 -työryhmän ehdotus. Sisäministeriön julkaisuja 5/2013, 4-5; 8. Retrieved 18 January 2018 from http://julkaisut.valtioneuvosto.fi/bitstream/handle/10024/79043/Maahanmuuton\%20tule vaisuus\%202020\%20-\%20työryhmän\%20ehdotus.pdf

Statistics Finland (2017). Employment statistics. Retrieved 30.4. 2018 from www.stat.fi.

Surakka, T., Rantamäki, T. (2013). Työelämätaidot. Porvoo: Bookwell Oy, 140.

Vesikansa, J. (2008). Finnish industry constantly adapting to changing world. Retrieved from https://finland.fi/business-innovation/finnish-industry-constantly-adapting-to-achanging-world/ 